unless recorded now will be lost forever. Some of you may know where a trading post once stood, a settlement, or perhaps a place where an Indian tribe established their winter camp each year. These subjects with many others of their kind go to make up eerly Saskatchewan History.

We would also like to hear your ideas for permanently marking Saskatehewan Historic Sites. Some Provinces and many States in the U.S.A, have sone a long way in erecting Cairns and Highway Markers at spots of historic interest. Only a meagre start has been made along this line in Saskatchewan.

It has been done in other provinces; they found to know your country better meant to love it more. The marking of Sites which contributed to Provincial History leads to more study and a better understanding of the events which placed us where we are today. Such marking makes our Province more interesting to ourselves, as well as to visitors, and need not be confined to Historic Sites alone. Pre-History might be observed, such as Indian Battles. Gelosical oddities might be marked too, like the sinking hill south of Swift Current or Rock formations of Roche Percee. "Blue Jay" readers are invited to comment on the above suggestions.

\title{
An Archaeologist
}

\section{SEVENTH ANNUAL CHFISTMAS BIRD COUNT}

For the seventh consecutive year, we shall again be taking our annual Christmas Bird Count, and hone that all who have taken part in the past will again be out in force, as well as our new members. These winter counts have resulted in some very interesting data concerning our winter bird life.

The count is made on any one day between December 27 and January 3, but preferably between Christmas and New Years inclusive. Every species of bird seen should be recorded as well as the total number of each species. Notes should also be made as to weather, wind, temperature, depth of snow, number of miles travelled and the time the observer(s) spent afield. Food conditions, such as the abundance or scarcity of hangino dried fruit, maple seeds, weed seeds, etc., should be recorded.

The previous six counts have resulted in 58 species (or sub-species recognizable in the field) being recorded in Saskatchewan during the Christmas season.

\section{IS THE BLUE JAY TO CONTINUE? !!}

A group of us, living in Regina, who have missed the "Blue Jay" since March 1948 feel that we would like to do something to keep this bulletin alive. Our inquiry into the cause of its failure has led us to conclude that the trouble is not financial for the Museum has been donating all printing costs in an effort to encourage the "Blue Jey". Nor do we think the trouble lies in the hard-working Yorkton executive and editor. The trouble lies in ourselves. The members are directly responsible, there is nothing to nublish. When on October 31, the Yorkton Natural History Society executive sent in all. the material they had received since March, we found only half a dozen letters. This means that less than $3 \%$ of the membershir contributed during a seven month period. During this period the "BIue Jay" has missed two issues. We 